\title{
Author Correction: Modelling the end of the Acheulean at global and continental levels suggests widespread persistence into the Middle Palaeolithic
}

\author{
Alastair J. M. Key (1), Ivan Jarić \& David L. Roberts
}

Correction to: Humanities and Social Sciences Communications https://doi.org/10.1057/s41599-021-00735-8, published online 2 March 2021.

The original paper did not include sites assigned to transitional Acheulean cultures, except for the Fauresmith in Africa. To ensure the analyses are correct, the authors have now removed Qesem Cave from the 'North Africa and Near East' and 'Global 1b' OLE models. While the earliest occupation at Qesem predates the Acheulo-Yabrudian (Barkai et al., 2003), the levels with dates young enough to be included in the models come from this transitional complex. The authors re-ran the 'North Africa and Near East' and 'Global 1b' OLE models with Qesem Cave removed. Its removal resulted in only minor changes to the inferred extinction dates for the two models. The Methods, Results and Conclusions remain entirely unchanged.

The original 'North Africa and Near East' model results were:

\begin{tabular}{llll}
\hline$T_{\mathrm{E}}$ Mean & $T_{\mathrm{E}}$ & $T_{\mathrm{CI}}$ Mean & $T_{\mathrm{CI}}$ \\
Estimate & Resampling & Estimate & Resampling \\
175,892 & 174,938 & 143,176 & 147,052 \\
\hline
\end{tabular}

The revised 'North Africa and Near East' model results are:

\begin{tabular}{llll}
\hline$T_{\mathrm{E}}$ Mean & $T_{\mathrm{E}}$ & $T_{\mathrm{CI}}$ Mean & $T_{\mathrm{CI}}$ \\
Estimate & Resampling & Estimate & Resampling \\
174,288 & 173,806 & 135,189 & 140,456 \\
\hline
\end{tabular}

The original 'Global 1b’ model results were:

\begin{tabular}{llll}
\hline$T_{\mathrm{E}}$ Mean & $T_{\mathrm{E}}$ & $T_{\mathrm{CI}}$ Mean & $T_{\mathrm{CI}}$ \\
Estimate & Resampling & Estimate & Resampling \\
61,572 & 66,818 & $-63,770$ & $-42,652$ \\
\hline
\end{tabular}

The revised 'Global 1b' model results are:

\begin{tabular}{llll}
\hline$T_{\mathrm{E}}$ Mean & $T_{\mathrm{E}}$ & $T_{\mathrm{CI}}$ Mean & $T_{\mathrm{CI}}$ \\
Estimate & Resampling & Estimate & Resampling \\
62,404 & 68,211 & $-59,238$ & $-36,916$ \\
\hline
\end{tabular}

These changes have been made to the online and PDF versions of the paper. 
Published online: 28 October 2021

(c) Open Access This article is licensed under a Creative Commons Attribution 4.0 International License, which permits use, sharing, adaptation, distribution and reproduction in any medium or format, as long as you give appropriate credit to the original author(s) and the source, provide a link to the Creative Commons license, and indicate if changes were made. The images or other third party material in this article are included in the article's Creative Commons license, unless indicated otherwise in a credit line to the material. If material is not included in the article's Creative Commons license and your intended use is not permitted by statutory regulation or exceeds the permitted use, you will need to obtain permission directly from the copyright holder. To view a copy of this license, visit http://creativecommons.org/licenses/by/4.0/.

(C) The Author(s) 2021 